Arq. Bras. Med. Vet. Zootec., v.67, n.3, p.891-898, 2015

\title{
Relevant peptides of Taenia crassiceps for the diagnosis of bovine cysticercosis by immunoblot
}

\author{
[Peptídeos relevantes de Taenia crassiceps para o diagnóstico da \\ cisticercose bovina pelo immunoblot] \\ L.F. Silva, P.S.A. Pinto, C.T.S. Ducas, T.O. Santos, E.C.A. Nieto, R.P.M.G. Peixoto \\ Universidade Federal de Viçosa - Viçosa, MG
}

\begin{abstract}
Given the limited knowledge about the diagnosis of bovine cysticercosis by immunoblot, the aim of this study was to assess the applicability of this test, identifying key peptides with diagnostic value. Immunoblot assays were performed using total larval antigen of Taenia crassiceps and 60 sera of positive bovines for cysticercosis (30 naturally and 30 experimentally infected with $T$. saginata eggs), 30 sera of negative bovines for cysticercosis and 30 sera of bovines with other diseases (fascioliasis, hydatidosis and tuberculosis). The peptides of greater diagnostic importance, in descending order of accuracy (\%), were as follows: $6-8 \mathrm{kDa}(90.8 \%), 129-143 \mathrm{kDa}(74.2 \%), 99-105 \mathrm{kDa}(71.7 \%)$ and $14-19 \mathrm{kDa}(71.1 \%)$. Crossreactions, due to fascioliasis and hydatidosis, were observed in the four intervals of peptides highlighted. The results demonstrate that the total antigen of $T$. crassiceps has peptides with a high diagnostic potential; therefore, the immunoblot is useful in the diagnosis of bovine cysticercosis.
\end{abstract}

Keywords: Bovine cysticercosis, diagnosis, immunoblot, Taenia crassiceps, peptides

\section{RESUMO}

Tendo em vista o conhecimento limitado sobre o diagnóstico da cisticercose bovina pelo immunoblot, o objetivo deste trabalho foi avaliar a aplicabilidade desse teste, identificando os principais peptídeos com valor diagnóstico. Foram realizados ensaios de immunoblot, utilizando antígeno total de larva de Taenia crassiceps e 60 soros de bovinos positivos para a cisticercose (30 naturalmente e 30 experimentalmente infectados com ovos de T. saginata), 30 soros de bovinos negativos para a cisticercose e 30 soros de bovinos com outras patologias (fasciolose, hidatidose e tuberculose). Os peptídeos de maior importância diagnóstica, em ordem decrescente de acurácia (\%), foram os seguintes: 6-8 kDa (90,8\%), 129-143 kDa (74,2\%), 99-105 kDa (71,7\%) e 14-19 kDa (71,1\%). Reações cruzadas, em decorrência da fasciolose e hidatidose, foram observadas nos quatro intervalos de peptídeos ressaltados. Os resultados demonstram que o antígeno total de $\mathrm{T}$. crassiceps possui peptídeos com alto potencial diagnóstico, sendo, portanto, o immunoblot útil no diagnóstico da cisticercose bovina.

Palavras-chave: Cisticercose bovina, diagnóstico, immunoblot, Taenia crassiceps, peptídeos

\section{INTRODUCTION}

The taeniasis-cysticercosis complex caused by Taenia saginata is responsible for two different occurrences and parasitic state in humans (taeniasis) and in cattle (cysticercosis). Bovine cysticercosis is responsible for considerable losses to the meat industry and represents a risk to food hygiene, since man achieves taeniasis by

Recebido em 3 de fevereiro de 2014

Aceito em 12 de março de 2015

E-mail: leticiaafs@gmail.com ingesting meat containing viable cysticerci (Dutra et al., 2012).

Since meat inspection, which is the main method for controlling bovine cysticercosis, has low sensitivity to detect cysts in carcasses with discrete infections, contaminated meat may reach the market, keeping the life cycle of the parasite within the population (Dorny et al., 2009). Thus, the development of a serological test that could 
be used as an auxiliary method for post-mortem inspection, in addition to being useful as an epidemiological tool for tracing the parasite, would contribute to the control of this zoonosis (Minozzo et al., 2004).

For the alternative diagnosis of porcine and human cysticercosis, the immunoblot has been employed by researchers as one of the serological techniques, showing performances of up to $100 \%$ in sensitivity and specificity. In these species, satisfactory results of immunological tests have been achieved using homologous antigens of Taenia solium larvae and heterologous of Taenia crassiceps larvae, whereas the latter, besides possessing peptides in common with the homologue, facilitates obtaining the consistency of antigen batches (Tsang et al., 1991; Pathak et al., 1994; Vaz et al., 1997; Bueno et al., 2000; Pinto et al., 2001).

The immunoblot is used very little in the diagnosis of bovine cysticercosis, and despite obtaining promising results, Girotto et al. (2009) emphasized the importance of performing variations in the protocol developed, in addition to testing other antigens, such as the total of $T$. crassiceps larvae, in order to confirm and verify the performance of this test for diagnostic purposes.

Given the excellent performance of the immunoblot for the diagnosis of porcine and human cysticercosis and the need to expand its use in the diagnosis of bovine cysticercosis, this work aimed to evaluate the frequency and performance rates of different peptides reactive to the total antigen of $T$. crassiceps larvae, against different categories of bovine sera, to identify those with significant potential diagnosis for bovine cysticercosis.

\section{MATERIAL AND METHODS}

In the immunoblot analyzes, the total antigen of $T$. crassiceps larvae was used. The larvae of $T$. crassiceps (cysticerci) were maintained in laboratory by intraperitoneal inoculation of female BALB/c mice at 30 days of age according to Vaz et al. (1997). For the production of the antigen, the living cysticerci were collected, frozen and then subjected to the following processing steps: overnight dehydration by lyophilization; grinding of the lyophilized cysticerci in porcelain mortar and weighing of the powder obtained; addition of $0.15 \mathrm{M}$ saline solution obtaining a final proportion of 6.5 to $10 \%$ (powder); homogenization on ice in Potter type homogenizer tissue; centrifugation of the material obtained at $17.400 \mathrm{~g} / 30 \mathrm{~min} / 4^{\circ} \mathrm{C}$. $0.25 \mathrm{M}$ PMSF (P7626, Sigma Chemical Co., US) was added to the supernatant as a protein inhibitor. The antigen was stored at $-20^{\circ} \mathrm{C}$ until it was used.

30 sera from bovines experimentally infected with 120,000 eggs of $T$. saginata, 30 sera from bovines naturally infected for cysticercosis, 30 sera of bovines negative for cysticercosis and other diseases and 30 sera from bovines without cysticercosis, but with other diseases such as hydatid disease (12), fascioliasis (12) and tuberculosis (6), exclusively, were analyzed by the immunoblot. The diagnoses were confirmed by a thorough macroscopic examination during the post mortem inspection routine held in slaughterhouses in accordance with the standards foreseen by the procedures of the Federal Inspection Service (Brasil, 1971).

In the preparation of membranes for the development of the immunoblot reactions, the peptides of the total antigen of $T$. crassiceps larvae were separated by SDS-PAGE at a concentration of $40 \mu \mathrm{g} / \mathrm{mL}$, according to their molecular weight, coupled with the molecular weight marker S8445 from 6.5 to $200 \mathrm{kDa}$ (Sigma Chemical Co., US). The peptides were then transferred from the gel to a nitrocellulose membrane of $0.45 \mu \mathrm{m}$ (Millipore Corp., US) according to the methodology described by Towbin et al. (1979). The transfer was done overnight at $4{ }^{\circ} \mathrm{C}$ with $50 \mathrm{~V}$ voltage and $120 \mathrm{~mA}$ amperage. After the transfer, the membrane was stained with Ponceau-S at $0.05 \%$ in bidistilled water for qualitative viewing of the transfer. The membranes were separated into $3 \mathrm{~mm}$ wide strips and were washed with $0.05 \%$ Tween-20 in saline solution $(0.15 \mathrm{M} \mathrm{NaCl})$ and then were subjected to immunoassay.

In the development of the immunoblot reactions, the strips had their remaining reactive sites blocked with skimmed milk powder at $5 \%$ in

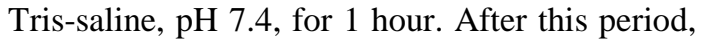
the excess blocking solution was removed. Serum samples were added at a 1:100 dilution in skimmed milk powder at $1 \%$ in Tris-saline $\mathrm{pH}$ 
7.4 for 1 hour. The strips were washed with $0.05 \%$ Tween-20 in Tris-saline $\mathrm{pH} 7.4$ six times every five minutes each. Then the bovine antiIgG A-5295 conjugate was added (Sigma Chemical Co., US) at 1:2000 dilution for 2 hours. The washing procedures were repeated. The reactions were revealed with chromogen solution (diaminobenzidine $5 \mathrm{mg} / 30 \mathrm{~mL}, 0.15 \%$ $\mathrm{H}_{2} \mathrm{O}_{2}$ in PBS pH 7.2) for 2 minutes, indicating reactive peptides on each strip. The reaction was then stopped with distilled water and the strips were dried on filter paper. The reagents were added in a volume of $1 \mathrm{~mL}$ per duct of the tub. The entire test was performed on an oscillating table, with constant and slow stirring, and at room temperature.

Optimal test conditions and sample dilutions were previously evaluated by titration using 3 positive (one experimentally and two naturally infected), 3 negative, and 3 control sera for checking the cross reactions.

The strips were scanned and analyzed by the Quantity One software, version 4.6 (Bio-Rad Laboratories, Hercules, CA, USA), from the identification of the bands of the molecular weight marker. With the identification of the reactive bands, performance rates of each peptide were determined according to the frequency of their reactions using the different categories of control serum. We determined the rates of sensitivity, specificity, positive and negative predictive values, and accuracy in order to identify peptides of greater diagnostic value for bovine cysticercosis and hence the criteria of positivity and negativity to the test.

This study was approved by the Comittee of Ethics in Research on Animal Use (Case 20/2012) of the Federal University of Viçosa.

\section{RESULTS}

The block of sera dilutions and conjugate that enabled the best visualization of the reactive bands with positive samples and better differentiation between positive and negative sera was 1:100 for the serum and 1:2000 for the conjugate. This block was adopted in the realization of the other immunoblot assays.

Tab. 1 shows the frequency of each reactive peptide in the immunoblot according to the category of bovine serum used. In a comprehensive analysis, one can observe that sera of bovines positive for cysticercosis showed the greatest amount of reactive peptides, followed by bovines with other illnesses (241) and negative bovines (238). Yet it appears that, among the positive sera, animals with experimental infection (414) had a higher number of reactive peptides than naturally infected animals (364). No peptide reacted with all the positive sera, with a variation in the frequency and intensity of production of antibodies against the different peptides.

Considering a minimum test accuracy of $70.0 \%$, four intervals of peptides defined in this study stood out among the rest with the best reactivity results (Tab. 2): 6-8, 14-19, 99-105 and 129-143 $\mathrm{kDa}$. The highest accuracy value was found in low molecular weight peptides, $90.8 \%$ for $6-8$ $\mathrm{kDa}$ peptides; peptides 14-19 $\mathrm{kDa}$, of low molecular weight, also had high accuracy at $71.1 \%$. As for those of high molecular mass, they obtained $74.2 \%$ and $71.7 \%$ for $99-105 \mathrm{kDa}$ and 129-143 kDa peptides, respectively.

Low frequency of cross-reactions were observed with these major peptides and occurred only with bovines from cattle with fascioliasis and hydatidosis; remarking that sera from animals with TB did not react with these peptides (Tab. 1).

Several reactive peptides obtained low accuracy, since they presented a sensibility and specificity differing from each other, either by reacting with both positive and negative sera and other diseases, or by not reacting with positive sera. These are the peptides $21-23$ to $96-98 \mathrm{kDa}, 106-$ 109 to $110-127 \mathrm{kDa}$, and $144-151$ to $182-184 \mathrm{kDa}$. For this reason, these peptides were considered of low diagnostic value, showing that the exclusive presence of these reactive peptides is not able to confirm the result for bovine cysticercosis. 
Table 1. Frequency of response of peptides in immunoblot in each category of sera, using a total antigen of $T$. crassiceps larvae

\begin{tabular}{|c|c|c|c|c|c|c|}
\hline \multirow{3}{*}{$\begin{array}{l}\text { Peptide } \\
\text { (kDa) }\end{array}$} & \multicolumn{6}{|c|}{ Serum Category } \\
\hline & \multirow{2}{*}{$\begin{array}{c}\text { Positive } \\
\text { Experimental }\end{array}$} & \multirow{2}{*}{$\begin{array}{l}\text { Positive } \\
\text { Natural }\end{array}$} & \multirow[b]{2}{*}{ Negative } & \multicolumn{3}{|c|}{ Other Pathologies } \\
\hline & & & & Fasciolosis & Hydatidosis & Tuberculosis \\
\hline $182-184$ & 0 & 1 & 2 & 0 & 0 & 0 \\
\hline 179 & 0 & 0 & 1 & 0 & 0 & 0 \\
\hline $161-168$ & 0 & 3 & 4 & 0 & 1 & 0 \\
\hline $144-151$ & 3 & 8 & 3 & 0 & 0 & 0 \\
\hline $129-143$ & 9 & 20 & 0 & 2 & 1 & 0 \\
\hline $110-127$ & 24 & 30 & 18 & 4 & 10 & 1 \\
\hline $106-109$ & 13 & 12 & 11 & 1 & 1 & 1 \\
\hline $99-105$ & 30 & 20 & 9 & 7 & 5 & 0 \\
\hline $96-98$ & 7 & 10 & 0 & 7 & 3 & 2 \\
\hline $94-95$ & 4 & 2 & 3 & 6 & 5 & 1 \\
\hline 93 & 3 & 9 & 0 & 2 & 0 & 2 \\
\hline $91-92$ & 5 & 5 & 1 & 2 & 1 & 0 \\
\hline $86-90$ & 14 & 15 & 15 & 5 & 5 & 3 \\
\hline $81-85$ & 20 & 19 & 17 & 7 & 5 & 4 \\
\hline 80 & 3 & 4 & 0 & 2 & 1 & 0 \\
\hline $76-79$ & 16 & 8 & 9 & 5 & 3 & 5 \\
\hline $71-75$ & 13 & 14 & 20 & 6 & 4 & 4 \\
\hline 70 & 5 & 3 & 0 & 1 & 0 & 0 \\
\hline $66-69$ & 10 & 14 & 12 & 4 & 2 & 2 \\
\hline $61-65$ & 20 & 6 & 11 & 5 & 2 & 3 \\
\hline $54-60$ & 21 & 17 & 13 & 3 & 8 & 4 \\
\hline $52-53$ & 14 & 4 & 1 & 2 & 2 & 1 \\
\hline $48-51$ & 14 & 8 & 14 & 3 & 2 & 2 \\
\hline $46-47$ & 9 & 8 & 1 & 0 & 2 & 1 \\
\hline $40-45$ & 19 & 12 & 10 & 6 & 5 & 1 \\
\hline 34-39 & 28 & 30 & 23 & 8 & 6 & 3 \\
\hline $32-33$ & 7 & 6 & 0 & 0 & 0 & 0 \\
\hline $29-31$ & 30 & 24 & 19 & 7 & 5 & 4 \\
\hline $25-28$ & 12 & 10 & 18 & 7 & 7 & 3 \\
\hline $21-23$ & 7 & 4 & 0 & 2 & 0 & 0 \\
\hline $14-19$ & 19 & 11 & 1 & 2 & 1 & 0 \\
\hline $9-13$ & 5 & 7 & 2 & 0 & 0 & 0 \\
\hline 6-8 & 30 & 20 & 0 & 1 & 0 & 0 \\
\hline Total & 414 & 364 & 238 & & 241 & \\
\hline
\end{tabular}

According to the physical appearance of reactive bands, Figure 1 illustrates the characteristic strips for each category of sera analyzed. The lower molecular weight bands were presented in the form of wide bands, resembling spots evident in the strips. In some reactions these stains showed more intense colors than others. The $29 \mathrm{kDa}$ band, quite often in different categories of sera, presented itself in the shape of a line, but thicker and in deeper color than the others. As for the higher molecular weight bands, they were observed as thin lines, which may, however, be confused with staining due to sometimes being positioned very close to each other, yet, the color varied from intense to light.
In Figure 1 we can also see how the low molecular peptides are common in positive samples and virtually absent in negative samples and other pathologies.

\section{DISCUSSION}

The order of frequency of reactive peptides obtained in this work was also observed by Pinto et al. (2001) when using the same categories of sera from porcines in immunoblot for the diagnosis of porcine cysticercosis. Girotto (2007) found the opposite result for positive sera, with sera from bovines naturally infected with eggs of $T$. saginata presenting a higher number of reactive peptides than sera from experimentally infected bovines. 
Relevant peptides...

Table 2. Performance rates of peptides reactive in immunoblot, using total antigen of T. crassiceps larvae

\begin{tabular}{|c|c|c|c|c|c|}
\hline \multirow[b]{2}{*}{$\begin{array}{l}\text { Peptide } \\
\text { (kDa) }\end{array}$} & \multicolumn{5}{|c|}{ Performance rates $(\%)$} \\
\hline & Sensibility & Specificity & $\begin{array}{c}\text { Positive Predictive } \\
\text { Value }\end{array}$ & $\begin{array}{c}\text { Negative } \\
\text { Predictive Value }\end{array}$ & Accuracy \\
\hline $182-184$ & 1.7 & 96.7 & 33.3 & 49.6 & 49.2 \\
\hline 179 & 0.0 & 98.3 & 0.0 & 50.4 & 49.2 \\
\hline $161-168$ & 5.0 & 91.7 & 37.5 & 49.1 & 48.3 \\
\hline $144-151$ & 18.3 & 95.0 & 78.6 & 53.8 & 56.7 \\
\hline $129-143$ & 48.3 & 95.0 & 90.6 & 64.8 & 71.7 \\
\hline $110-127$ & 90.0 & 45.0 & 62.1 & 81.8 & 67.5 \\
\hline $106-109$ & 41.7 & 76.7 & 64.1 & 56.8 & 59.2 \\
\hline $99-105$ & 83.3 & 65.0 & 70.4 & 79.6 & 74.2 \\
\hline $96-98$ & 28.3 & 80.0 & 58.6 & 52.7 & 54.2 \\
\hline $94-95$ & 10.0 & 75.0 & 28.6 & 45.5 & 42.5 \\
\hline 93 & 20.0 & 93.3 & 75.0 & 53.8 & 56.7 \\
\hline $91-92$ & 16.7 & 93.3 & 71.4 & 52.8 & 55.0 \\
\hline $86-90$ & 48.3 & 53.3 & 50.9 & 50.8 & 50.8 \\
\hline $81-85$ & 65.0 & 45.0 & 54.2 & 56.3 & 55.0 \\
\hline 80 & 11.7 & 95.0 & 70.0 & 51.8 & 53.3 \\
\hline 76-79 & 40.0 & 63.3 & 52.2 & 51.4 & 51.7 \\
\hline $71-75$ & 45.0 & 43.3 & 44.3 & 44.1 & 44.2 \\
\hline 70 & 13.3 & 98.3 & 88.9 & 53.2 & 55.8 \\
\hline $66-69$ & 40.0 & 66.7 & 54.5 & 52.6 & 53.3 \\
\hline $61-65$ & 43.3 & 65.0 & 55.3 & 53.4 & 54.2 \\
\hline $54-60$ & 63.3 & 53.3 & 57.6 & 59.3 & 58.3 \\
\hline $52-53$ & 30.0 & 90.0 & 75.0 & 56.3 & 60.0 \\
\hline $48-51$ & 36.7 & 65.0 & 51.2 & 50.6 & 50.8 \\
\hline $46-47$ & 28.3 & 93.3 & 81.0 & 56.6 & 60.8 \\
\hline $40-45$ & 51.7 & 63.3 & 58.5 & 56.7 & 57.5 \\
\hline $34-39$ & 96.7 & 33.3 & 59.2 & 90.9 & 65.0 \\
\hline $32-33$ & 21.7 & 100.0 & 100.0 & 56.1 & 60.8 \\
\hline $29-31$ & 90.0 & 41.7 & 60.7 & 80.6 & 65.8 \\
\hline $25-28$ & 36.7 & 41.7 & 38.6 & 39.7 & 39.2 \\
\hline $21-23$ & 18.3 & 96.7 & 84.6 & 54.2 & 57.5 \\
\hline $14-19$ & 50.0 & 93.3 & 88.2 & 65.1 & 71.1 \\
\hline $9-13$ & 20.0 & 96.7 & 85.7 & 54.7 & 58.3 \\
\hline $6-8$ & 83.3 & 98.3 & 98.0 & 85.5 & 90.8 \\
\hline
\end{tabular}

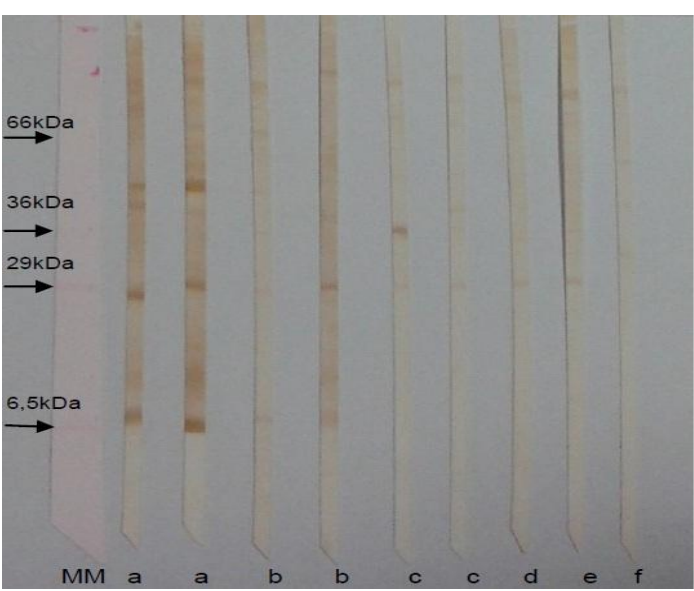

Figure 1. Reactive band patterns in the different categories of bovine sera used in immunoblot assays: MM, molecular mass marker; $a$, positive experimental for cysticercosis; $b$, positive natural for cysticercosis; $c$, negative for cysticercosis and other diseases; $d$ with hydatidosis; $e$, with fascioliasis; $f$, with tuberculosis.
The absence of a peptide to react with all samples coincides with the results obtained by other researchers in studies of bovine (Girotto et al., 2009), porcine (Tsang et al., 1991) and human (Tsang et al., 1989; Vaz et al., 1997) cysticercosis. Furthermore, the observed diversity of antibodies produced against reactive peptides confirms the heterogeneity of the host's immune response against the parasite (Vaz et al., 1997).

The peptides that showed accuracy above $70 \%$ can be considered the most important for the diagnosis of bovine cysticercosis, since they were the most efficient in differentiating sera of bovines positive and negative for cysticercosis. And although 9-13kDa peptides were not among those of highest accuracy $(58.8 \%)$, such peptides accused high differentiation power of positive 
samples from samples of nonspecific or crossreactions, showing a specificity of $96.7 \%$, which helps to reaffirm the importance of the immunoblot method as a confirmatory diagnosis of bovine cysticercosis, especially when considering the low molecular weight peptides as a defining criterion of positivity.

Girotto et al. (2009) also emphasized the importance of low molecular weight peptides of the antigen of $T$. crassiceps larvae in the diagnosis of bovine cysticercosis, especially those of 4-6, 14 and $18 \mathrm{kDa}$, which showed accuracy values above $80 \%$, confirming the results obtained in this study. However, according to these same authors, $100-106 \mathrm{kDa}$ peptides showed low accuracy values $(55.6 \%)$, therefore having a low diagnosis potential and confronting the results obtained. Brandt et al. (1992), using an antigen of T. saginata larvae, verified the diagnostic value of the $100 \mathrm{kDa}$ peptide, while Vicentini-Oliveira et al. (2010), in addition to the $100 \mathrm{kDa}$ peptide, highlighted the low molecular weight peptides $(<18 \mathrm{kDa})$ as important for the diagnosis of bovine cysticercosis, both agreeing with the results obtained in this study.

In another line of research, but coinciding with the results of this study, Pinto et al. (2001) showed a similar pattern on the immunoblot for the diagnosis of porcine cysticercosis with the low molecular weight peptides $(<25 \mathrm{kDa})$ of the total antigen of $T$. crassiceps among those of highest importance for the diagnosis of porcine cysticercosis. However, the authors considered the high molecular weight peptides of little specificity for the diagnosis of porcine cysticercosis, this did not occur in this research since the $99-105$ and $129-143 \mathrm{kDa}$ peptides showed high value of accuracy for the diagnosis of bovine cysticercosis.

Still, agreeing with the results of this study, Ito et al. (1998) and Ito et al. (1999) highlighted the importance of the $10 \mathrm{kDa}$ peptide in the diagnosis of human and porcine cysticercosis, respectively. But Macedo et al. (2002), Pardini et al. (2002) and Peralta et al. (2010) have obtained satisfactory results for human cysticercosis with the 14 and $18 \mathrm{kDa}$ peptides being highly sensitive and specific. Gottstein et al. (1987) reported the specificity of another low molecular weight peptide in the diagnosis of human cysticercosis, the $8 \mathrm{kDa}$.

Tsang et al. (1989) and Tsang et al. (1991) identified seven glycoproteins of the antigen of $T$. solium specific for the diagnosis of human and porcine cysticercosis, respectively, and these peptides are among those of 13, 14 and $18 \mathrm{kDa}$. They also observed that proteins with molecular weight below $13 \mathrm{kDa}$ were recognized by the majority of patients with cysticercosis (Tsang et al., 1989).

As noted, several authors reported the immunodominance of low molecular weight peptides in human and porcine cysticercosis and, now, confirming the results of Girotto et al. (2009) and Vicentini-Oliveira et al. (2010), also in bovine cysticercosis.

The adverse reactions observed in animals with these peptides considered important in the diagnosis of bovine cysticercosis may be due to the nonspecific response, since these animals were raised in the field, exposed to various pathogens, causing some nonspecific immune response in these animals.

Despite the occurrence of cross-reactions with peptides of diagnostic value, the frequency observed was low, especially with the low molecular weight peptides, confirming the specificity of the test and the importance of taking into account the correct peptides for the diagnosis of bovine cysticercosis. Pinto et al. (2001) also observed a cross-reaction with hydatidosis in immunoblot for the diagnosis of swine cysticercosis. These reactions can be a consequence of the antigenic overlap between cestodes and other parasites (Smith et al., 1990).

Thus, the correct interpretation of the results of immunoblot depends almost entirely on the correct identification of the bands with diagnostic power. However, in addition to the molecular weight of these bands, it is also important to verify their physical appearance (width) (Larralde et al., 1989; Tsang et al., 1989). The different staining intensities of the bands were probably due to variation of the amount of antibodies produced between hosts (Tsang et al., 1991). The band patterns obtained (Figure 1) were similar to those observed by Girotto et al. (2009). 
Another important point in a diagnostic test is the determination that a sample is positive or negative. In this issue, Tsang et al. (1989) established as a criterion for positivity the reaction of the sample with at least one of the peptides of diagnostic importance. Now Pinto et al. (2001) suggest that a sample is considered positive when it is reactive with at least two peptides considered specific. The first criterion contributes to the increased sensitivity of the test, while the latter favors specificity, so the positive criterion to be adopted depends on the purpose of the study or diagnosis (Pinto et al., 2001).

Therefore, when determining the positivity and negativity of a sample for bovine cysticercosis by immunoblot, one should take into account the reactivity of one or more of the following peptides: $6-8,14-19,99-105$ or $129-143 \mathrm{kDa}$, based on the results obtained in this study.

\section{CONCLUSIONS}

The total antigen of Taenia crassiceps larvae has peptides with high diagnostic value for bovine cysticercosis, and the favorable performance obtained with low molecular weight peptides reaffirms its diagnostic power previously verified in the diagnosis of the same disease in porcines and humans. These results accredit the immunoblot as a reliable diagnostic method for bovine cysticercosis, which will contribute to a more effective control of the disease, since it is able to differentiate between positive and negative bovines, with high performance rates.

\section{ACKNOWLEDGMENTS}

The authors thank CNPq, CAPES and FAPEMIG for the financial support for the research.

\section{REFERENCES}

BRANDT, J.R.A.; GEERTS, S.; DE DEKEN, R. et al. A monoclonal antibody-based ELISA for the detection of circulating excretory-secretory antigens in Taenia saginata cysticercosis. Int. J. Parasitol., v.22, p.471477, 1992.

BRASIL. Ministério da Agricultura, Pecuária e Abastecimento. Inspeção de carnes: padronização de técnicas, instalações e equipamentos. Tomo I: Bovinos. Brasília, DIPOA/DICAR, 1971. 183p.
BUENO, E.C.; VAZ, A.J.; MACHADO, L.R. et al. Specific Taenia crassiceps and Taenia solium antigenic peptides for neurocysticercosis immunodiagnosis using serum samples. J. Clin. Microbiol., v.38, p.146-151, 2000.

DORNY, P.; PRAET, N.; DECKERS, N.; GABRIEL, S. Emerging food-borne parasites. Vet. Parasitol., v.163, p.196-206, 2009.

DUTRA, L.H.; GIROTTO, A.; VIEIRA, R.F.C. et al. The prevalence and spatial epidemiology of cysticercosis in slaughtered cattle from Brazil. Semina Ciênc. Agrar., v.33, p.1887-1896, 2012.

GIROTTO A. Avaliação do imunoblot no diagnóstico da cisticercose bovina. 2007. 74f. Dissertação (Mestrado em Medicina Veterinária) - Universidade Federal de Viçosa, Viçosa, MG.

GIROTTO, A.; PINTO, P.S.A.; DIAS, J.C.O. et al. Detecção de peptídeos importantes para o diagnóstico da cisticercose bovina no immunoblot. Cienc. Rural, v.39, p.1147-1151, 2009.

GOTTSTEIN, B.; ZINI, D.; SCHANTZ, P.M. Species-specific immunodiagnosis of Taenia solium cysticercosis by ELISA and immunoblotting. Trop. Med. Parasitol., v.38, p.299-303, 1987.

ITO, A.; PLANCARTE, A.; MA, L. et al. Novel antigens for neurocysticercosis: simple method for preparation and evaluation for serodiagnosis. Am. J. Trop. Med. Hyg., v.59, p.291-294, 1998.

ITO, A.; PLANCARTE, A.; NAKAO, M. et al. ELISA and immunoblot using purified glycoproteins for serodiagnosis of cysticercosis in pigs naturally infected with Taenia solium. J. Helminthol., v.73, p.363-365, 1999.

LARRALDE, C.; MONTOYA, R.M.; SCIUTTO, E. et al. Deciphering western blots of tapeworm antigens (Taenia solium, Echinococcus granulosus, and Taenia crassiceps) reacting with sera from neurocysticercosis and hydatid disease patients. Am. J. Trop. Med. Hyg., v.40, p.282-290, 1989.

MACEDO, H.W.; PERALTA, R.H.S.; CIPRIANO, A. et al. Avaliação de testes imunológicos para o diagnóstico da neurocisticercose. J. Bras. Patol. Med. Lab., v.38, p.93-103, 2002.

MINOZZO, J.C.; THOMAZ-SOCCOL, V.; OLORTEGUI, C.C. et al. Teste imunoenzimático (enzyme-linked immunosorbent assay) para diagnóstico da cisticercose bovina e estudo da cinética de produção de anticorpos contraCysticercus bovis. Cienc. Rural, v.34, p.857-864, 2004. 
PARDINI, A.X.; PERALTA, R.H.; VAZ, A.J. et al. Use of Taenia crassiceps cysticercus antigen preparations for detection of antibodies in cerebrospinal fluid samples from patients with neurocysticercosis (Taenia solium). Clin. Diagn. Lab. Immunol., v.9, p.190-193, 2002.

PATHAK, K.M.L.; ALLAN, J.C.; ERSFELD, K.; CRAIG, P.S. A western blot and ELISA assay for the diagnosis of Taenia solium in pigs. Vet. Parasitol., v.53, p.209-217, 1994.

PERALTA, R.H.; ESPÍNDOLA, N.M.; PARDINI, A.X. et al. Taenia crassiceps cysticerci: Characterization of the 14-kDa glycoprotein with homologies to antigens from Taenia solium cysticerci. Exp. Parasitol., v.124, p.295-300, 2010.

PINTO, P.S.A.; VAZ, A.J.; NAKAMURA, P.M.; GERMANO, P.M.L. Immunoblot analysis using antigen from Taenia crassiceps cysticerci in the diagnosis of swine cysticercosis. Bol. Chil. Parasitol., v.56, p.36-42, 2001.

SMITH, H.J.; SNOWDON, K.E.; GREGORY, D.; FINLEY, G.G. Assessment of an enzymelinked Immunosorbent assay using a Taenia hydatigena fraction antigen in the diagnosis of cysticercosis in cattle. Can. J. Vet. Res., v.54, p.299-300, 1990 .
TOWBIN, H.; STAEHELIN, T.; GORDON, I. Electrophoretic transfer of proteins from polyacrylamide gels to nitrocellulose sheets: procedure and some applications. Proc. Nat. Acad. Sci., v.76, p.4350-4352, 1979.

TSANG, V.C.W.; BRAND, J.A.; BOYER, A.E. An enzyme-linked immunoelectrotransfer blot assay and glycoprotein antigens for diagnosing human cysticercosis (Taenia solium). J. Infect. Dis., v.159, p.50-59, 1989.

TSANG, V.C.M.; PILCHER, J.A.; ZHOU, W. et al. Efficacy of the immunoblot assay for cysticercosis in pigs and modulated expression of distinct $\operatorname{IgM} / \operatorname{IgG}$ activities to Taenia solium antigens in experimental infections. Vet. Immunol. Immunopathol., v.29, p.69-78, 1991.

VAZ, A.J.; NUNES, C.M.; PIAZZA, R.M.F. et al. Immunoblot with cerebrospinal fluid from patients with neurocysticercosis using antigen from cysticerci of Taenia solium and Taenia crassiceps. Am. J. Trop. Med. Hyg., v.57, p.354357, 1997.

VICENTINI-OLIVEIRA, J.C.; GOLIM, M.A.; PAULAN, S.C. et al. Taenia saginata: Production and characterization of monoclonal antibodies against Taenia saginata metacestode antigens. Exp. Parasitol., v.126, p.621-625, 2010 . 